\title{
In Search for Femina Grata: Revanchist Urban Policies in a Historical District of Turkey
}

\author{
"Ulus"un Makbul Kadınları: Rövanşist Kent Politikaları \\ Bağlamında Bir Değerlendirme
}

\author{
Mine EGBATAN \\ University of Arizona, College of Social and Behavioral Sciences, School of Anthropology, USA \\ Arizona Üniversitesi, Sosyal ve DavranışB Bilimleri Enstitüsü, Antropoloji Bölümü, ABD \\ mineegbatan@email.arizona.edu \\ ORCID ID 0000-0003-4210-0838
}

DOI: $10.5505 /$ jas.2021.06078

\begin{abstract}
This study uses the analytical lens of the "revanchist city" to examine the neoliberal urban renewal processes in Ulus, a historical district in Ankara, Turkey's capital city, in which prostitutes work. This study takes a comparative approach to examine the construction of femina grata by analyzing the law, practices, and political projects in relation to women in the radical modernity period of Turkey. It also analyzes current neoliberal revanchist interventions that have taken place in Ulus and looks at their gendered meanings in accordance with implemented urban renewal strategies. I mainly argue that neoliberal revanchist policies carried out in Ulus aim to cultivate city spaces for capital and attract families who engage in pious activities, and thus do not include those women and families who remain secular through the creation of a moment of "triple dualism."
\end{abstract}

Keywords: Revanchist city, Femina grata, Public woman, Ulus, Triple dualism, Ankara

\section{$\ddot{O} z$}

Bu çalışma "rövanşist kent" kavramın analitik bir lens olarak kullanarak Ulus bölgesindeki neoliberal kentsel yenileme sürecinin "makbul" kadın kurgusuna etkilerini tartışmaktadır. Ulus bölgesinde bulunan Bentderesi genelevinin yıkılması sonrasında seks iş̧̧ileri bu bölgeden çeşitli şekillerde uzaklaştırıldı. Ulus bölgesi Ankara'nın manevi merkezi olarak pazarlanmaya başlandı ve muhafazakâr aile odaklı bir mekân haline geldi. Radikal modernite ve neoliberal rövanşist dönem olarak tanımladığım iki dönemde seks iş̧̧ilerine yönelik uygulamaları ve "makbul" kadının tanımının değişimine etkisini tartışacağım. "Üçlü ikilik" kavramını kullanarak "makbul" kadının tanımı değişirken seks iş̧̧ilerinin her daim bir "öteki” olarak kurgulandığına değinecek ve dolayısıyla ataerkilliğin süreklilik ve kopuşlarını analiz edeceğim.

Anahtar sözcükler: Rövanşist kent, Ulus, Seks iş̧̧ileri, Makbul kadın, Üçlü ikilik, Ankara

* The earlier version of this article was awarded University of Arizona School of Anthropology Dozier Award in 2020.

** Bu makalenin önceki versiyonu, 2020’de Arizona Üniversitesi Antropoloji Okulu Dozier Ödülü almaya hak kazanmıştır. 


\section{Introduction}

Bentderesi Brothel was located in Ulus district, a historical city center of Ankara, the capital of Turkey. When the brothel was demolished as part of the renovation of Ulus, this did not grab much attention, and after scanning the newspapers of the period to see how the abolishment of Bentderesi brothel was reported at the time, I found an interview with a sex worker who worked in Bentderesi brothel that was published in the right-wing Birgün newspaper (Şahin, 2017, 25 June). Other news pieces were actively promoting the abolishment of the brothel and emphasized that Ulus would now be a much more beautiful place where Ankaralılar ${ }^{1}$ would be able to better enjoy visiting and spending time. I interviewed the female journalist who had met the sex worker in the Bentderesi brothel, both to hear about her experience, as well as to hopefully learn how I could contact sex workers as part of my fieldwork. The journalist told me that the the most impressive moment she experienced during her interview with the sex worker was about a photograph that was to be used in the news piece. While her face was clearly seen in the photograph, the sex worker turned her back to the camera. "After that photo," said the journalist, "I went back to my safe and secure life; however, she went to Bentderesi to work" (Personal interview, July 2013).

This particular moment that journalist attracted my attention to was merely the reflection of the patriarchal power structure that controls, regulates, and dominates the lives and bodies of women, in which the lives of sex workers are not regarded as lives that are "worthy of rights and protections" (Butler, 2012, p. 10). On the contrary, the lives of such individuals are constructed as being easily disposable in order to protect the "decent" lives of other families and women. While I consider this to be an ongoing issue throughout Turkey's different political periods, the construction of the notion of "decent" women has been subject to change.

This study draws upon Ilhan Tekeli's (2010) specification of the three phases of political transition in Turkey, namely, the periods of Radical Modernity (1923-1950), Populist Modernity (1950-1980), and the Erosion of Modernity (1980-), to primarily focus on the first and last periods. The study renames the latter, "Erosion of
Modernity," as the "revanchist period," in order to focus on neoliberal urban renewal (in Ulus). With "Radical Modernity," Tekeli is referring to the establishment of the New Republic through socio-spatial processes that aimed at "the transformation of the country in a nationstate," and the transformation of cities into "places of modernity" (Tekeli, 2010, p. 36). However, 'Erosion of Modernity' refers to the neoliberal period that began in Turkey in the 1980s (Tekeli, 2010, p. 39), in which measures taken in the management of the city of Ankara are based on conservative Islamic values.

The expression of neoliberalism in the city has resulted in extreme segregation in which public and urban spaces are reconstructed for the benefit of "decent" citizens. Influential since the 1970s, neoliberalism as an ideology emphasizes the importance of market values and capital accumulation, as opposed to Keynesian welfare policies which privilege redistributive justice. Neoliberal ideology has political and economic dimensions which aim to "extend market discipline, competition, and commodification throughout all sectors of society" (Brenner \& Theodore, 2002, p. 350). While the supranational and national parameters of neoliberalism have attracted attention in the literature in terms of geopolitical economy, it is argued that neoliberalism is at the subnational level, i.e. at the level of cities and city-regions, and therefore needs to be elaborated more systematically. In the words of Brenner and Theodore, "cities have become strategically crucial geographical areas in which a variety of neoliberal initiatives have been articulated" (2002, p. 351). The market and profit-driven nature of neoliberalism have been highly influential in the reconstruction and rebuilding of city spaces, which often excludes certain groups of people. As Lefebvre (1991) emphasizes, this production of space is necessary for "the long-term survival of capitalism."

An increase in marketable value is enabled through the displacement, stigmatization, and discrimination of "marginal" people, including the poor, ethnic minorities, LGBTI people, and sex workers. Neil Smith (1996) developed the idea of the "revanchist city" in which the middle-class fear of the loss of economic privileges results in a reaction against the "undesirables" (Aalbers, 2011) who are held responsible for the urban decline and unrest in the city. ${ }^{2}$ The revanchist city aims to claim city spaces

1 Ankaralılar means "the citizens of Ankara," excluding sex workers.

2 The term "revanchist city" stems from the French word "revanche," which refers to the middle-class reaction against revolutionary movements during the Paris commune. 
for capital accumulation and the perceived safety of the middle class. Smith's (1996) conceptualization of revanchism is open to multiple readings and is applicable to diverse places, and so may take different forms in different urban contexts. In this study, I use the analytical lens of the revanchist city to examine the neoliberal urban renewal (renovation) in Ulus, a historical district in the city of Ankara, the capital of Turkey.

During Turkey's period of radical modernity, prostitution was regulated by sex workers being regulated, and if necessary, incarcerated, by a brothel system established via the Public Health Law (No. 1593) in $1930^{3}$ and subsequent by-laws. More recently, during the urban renewal process, sex workers' workspaces have been demolished, and the workers themselves subject to exclusion, violence, and displacement. I suggest that these two practices, which are implemented in different political periods, as being methods of constructing a femina grata. ${ }^{4}$ This term means 'the accepted female' (c.f. persona non grata) and refers to a woman which is defined as being "decent," namely, a "private" woman, and the meaning and construction of this term are subject to change. During Turkey's Republican period, a change occurred due to the political projects being pursued, and a significant shift is identifiable between radical modernity and neoliberal urban revanchism.

Consequently, this study uses the term "femina communa" to refer to a "common" woman, or prostitute (as common property), or the "public" woman. The Public Health Law in Turkey defines prostitution primarily through the terms for brothel and prostitute, "genel ev" and "genel kadın" meaning literally, "general house" and "general woman." Thus, the sex-worker is called "a general woman" or "a public woman." The term "Femina grata" is used in this study to negate "femina communa," whose meaning is fixed by the law. This way of seeing the public and private woman enables us to characterize the patterns in which the (patriarchal) projection of the heteronormative (the decent woman) is maintained through interpretations of the other (as a sex worker). Analytically, therefore, it is the unchanging (legally defined) other that fixes the mutable (politically determined) norm.

This paper follows a comparative approach to determine the construction of femina grata by first considering legal practices and political projects in relation to women in the period of radical modernity, and by then turning to current, neoliberal revanchist interventions in Ulus and their gendered meanings. Popular modernity is not considered in the study as it was a transitionary period that did not have any particular relevance to sex work and transformations in the Ulus district. The paper consists of three main parts. The first addresses the changes in meanings of the district of Ulus; the second analyzes the construction of femina communa through the Public Health Law (No. 1593, 1930) and the meanings of femina grata in the period of radical modernity, and the third focuses on the practices of neoliberal urban policies in Ulus that exclude sex workers and construct a femina grata with religious tendencies. The main argument of the paper is that the neoliberal policies implemented in Ulus aim, by creating a moment or configuration of what I call triple dualism, to cultivate city spaces for the capital and to attract women and families that enjoy pious, rather than secular, activities. The triple dualism is due to the pairings, derived from pious, secular, and sex work, that are applied to women and historically situated in Turkey. The term itself is an essential component of making sense of how women were constructed during the neoliberal revanchist period. I have based this argument on the indepth interviews with municipality council members, city planners, sex workers' rights activists, and sex workers I conducted in Ankara's Ulus district between 2013 and $2017 .^{5}$ The data I obtained from municipality council members and city planners provided allowed me to appreciate reasons behind the decisions being made in the transformation of Ulus district. I spent a lot of time in the Red Umbrella Sexual Health and Human Rights Association, and was introduced to the sex workers who had formerly worked in the brothel through Belgin, a sex worker rights activist. I also relied on walking ethnography (Pink, 2007; Edensor, 2010; Degen \& Rose, 2012),

3 Original title of the law in Turkish: Umumi Hıfzıssıhha Kanunu, https://www.resmigazete.gov.tr/arsiv/1489.pdf

4 Sex workers are described as being "public woman" in the feminist literature in which public/private dichotomies are considered (i.e: Wright, 2006; Pateman, 1983; MacKinnon, 1989). Inspired by the term "persona non grata", I use "femina grata" instead of "private woman", and "femina communa" instead of "public woman."

5 I interviewed seven people from the municipality, two sex worker rights activists and other sex workers visiting the Association, seven sex workers who had previously worked in the brothel, and women visiting who was visiting Hac1 Bayram Mosque in the Ulus district. 
which enabled me to better understand the district's spatial dynamics and encounter sex workers. Belgin introduced me to the alternative spatiality of the Ulus district which helped me encounter sex workers. Street interviews were brief in order to avoid the attention of the police or public, whereas home interviews were extended and detailed. The aim of the fieldwork is to consider the following question: Do the changing landscapes of Ulus during such a neoliberal revanchist period constitute revanchism against the image of "decent" (or "private") women?

\section{Revanchism in Ulus}

Many scholars use the term "urban revanchism" to refer to the economic, political, and ideological processes behind urban restructuring (Atkinson, 2003; Swanson, 2007; Uitermark \& Duyvendak, 2008). A primary aspect of the revanchist city is a reorganization of urban public spaces for economic restructuring (i.e., to market and commodify). Two intertwined processes go hand-inhand with urban revanchism: the devaluation of those who are incompatible with the economic restructuring, and the pursuit of a selective process regarding what to include in the urban spaces, as determined by marketing requirements (referring especially to the image). These twin processes work on the "exclusion, displacement or repression of cultures and histories deemed 'undesirable' in the discursive and/or physical public sphere of the city" (Colomb, 2012, p. 21). Urban revanchism in Ulus follows a similar pattern, not only displacing economically marginalized groups, such as sex workers and their workspaces, but also privileging certain images of Ulus through a process of selection from the various meanings attributed to Ulus over the decades of the Republic.

Ulus has played host to a diversity of practices during the Republic, ranging from radical modernity to periods of neoliberal revanchism. Ulus was the principal economic and administrative center of the early Republican period, and was also a center of religious life as it was the location of the famous and historical Hacı Bayram Mosque. Sex work has been a part of Ulus since the establishment of one of the first brothels near Kengri Gate, currently known as Çankırı Street, in 1925 (Evered \& Evered, 2013, p. 280).

Among the first moves of the new government after the establishment of the Turkish Republic in 1923 were the declaration of Ankara as the capital city (in order to move the capital away from the Ottoman seat at Istanbul) and the initiation of an urban modernization project as a model for other cities in the new country. Through the Jansen Plan, which was named after the German architect, Hermann Jansen, who won a competition to design the new capital, Ankara was developed as a modern and secular city, within which Ulus was assigned a significant public space as the new regime's bureaucratic, political, social, and ideological center.

A large, European style, central square was created in Ulus to house parliamentary buildings, banks, a railway station, and small businesses. Various national ceremonies were conducted around its Victory Monument, which was an early symbol of the Republic. Originally named the National Sovereignty Square (Hakimiyet- $i$ Milliye Meydanı), Ulus Square, as it became, was "subjected to conscious interventions by the state in order... to embody certain representational aspects" (Batuman, 2015 , p. 885). Ulus was also a major economic center in the 1930s, as many banks were situated there. Several various locations, including Ankara Palas and Millet Garden, were developed as spaces for modern, secular life (Yalım, 2002, p. 182). Overall, the district was attributed symbolic importance to strengthen the image and power of the newly established regime; the very name "Ulus" means "nation." It can therefore be said that the design and development of Ulus as the center of the new state capital of Ankara aimed to establish and symbolize the health of the new nation. This vigorous modernity was in implicit contrast to the aged, imperial sickness of Istanbul.

Ulus was the center of Ankara until the Democrat Party came to power in the 1950s. The opposition to the Kemalist modernization project by the right-wing political inclinations of the Democrat Party lead to a politics of decay in Ulus, which culminated in the area being replaced by Kizılay as the city's political and economic center. This process can be regarded as the seeds of the following revanchism. During the more recent, neoliberal, revanchist period, and due to the influence of Melih Gökçek, Mayor of Ankara for the Justice and Development Party (Adalet ve Kalkınma Partisi, AKP) between 1994 and 2017, Ulus has undergone a revisionary urban renewal process in which the religious meanings of the district have been emphasized.

While Doğan (2005, p. 5) defines the period between 1994 and 1999 as a "revanchist period" in Ankara in respect 
to the municipal practices of Mayor Gökçek, he further argues that, although Gökçek did act against modernity, this did not mean he was totally opposed to Kemalist modernization, even though Islamic forms (practices, structures, etc.) were excluded from the public space. This is debatable, but there is no doubt that after 2002, following the AKP winning a landslide in the national election, there is explicit pursuing of a policy of neoliberal Islamism in which "urban space has become a significant means of capital accumulation" (Batuman, 2015, p. 893). In other words, it can be said that the period of AKP hegemony has become revanchist against the Kemalist modernization project. Following these changes in the municipal practices in Ulus, a reflection of the AKP's tendency to "blend market requirements and ideological desires" (Batuman, 2015, p. 893) can be seen. This has meant that instead of being a space of radical modernity, Ulus has become a space of religious conservatism that operates in conjunction with the capital.

The Ankara Greater Municipality initiated the Renovation Project of the Historical City Center of Ulus in 2005. One of the important indicators of the revanchism was the move to increase the marketability of Ulus as a center of religious activities by promoting the Hacı Bayram Mosque and creating an economy organized around Islamic religious values (Figure 1). The renovation project resulted in the destruction of buildings associated with Kemalist modernization, including historic banks from the radical modernity period (Şahin, 2017, 25 June). One municipality employee told me that Ulus is the spiri-

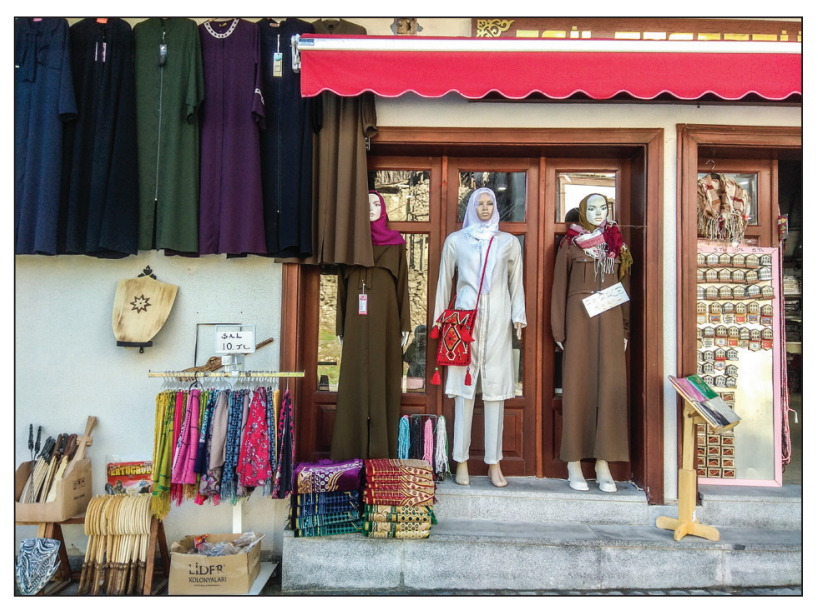

Figure 1. A store in the Ulus district. Photograph by: Mine Egbatan. tual center of Ankara, and such features of the space need to be highlighted (Personal interview, 2014). Another interviewee from the municipal council, representing the opposition Republican People's Party, emphasized that the shops in Ulus had been rented for ten years to individuals with religious tendencies and foundations, and this establishment of the radical modernity period had completely changed the symbolic meaning of Ulus (Personal interview, 2014).

As Lefebvre (1991, p. 27) notes, "social space is a social product," which implies that a constructed environment is produced socially, ideologically, and politically by those who use it. Although Smith (2002, p. 445) states that revanchist city practices merely allow the (upper) middle classes to "retake the control of the "political and cultural' economies of the largest cities," this does not apply in the case of Ulus as the people buying and renting property in that district are primarily from the lower middle classes. In other words, this group can be seen to be taking control (for the first time), not re-taking control (once again). Therefore, the case of Ulus is important as it demonstrates that neoliberalism as locally situated is not expressed in a single and pure form (Brenner \& Theodore, 2005).

As a corollary to the religiosity, the new economic restructuring of Ulus requires the elimination of sex workers and sex workspaces from the area as they are incompatible with the contemporary meaning of the transition. Schinkel, Suvarierol and Van Houdt (2011, p. 411) argue that "[f]rom a neoliberal strategy, citizens need to become active parties entering contracts between the state, society, market, and citizens." Female (mostly) sex workers are insignificant as subjects under neoliberal economic restructuring, however, and so are unable to 'enter contracts' with a local governance regime that wants to be rid of them. This group therefore becomes one of the revanchist-targeted, and economically marginal groups that are considered "unable to learn the lesson that neoliberalism now expects of its subjects" (Pratt, 1997, p. 181). In other words, sex workers are not only displaced from Ulus for "moral" reasons, but also because their practices are not regarded as income-generating (since they reduce real estate values). However, Esin, a former sex worker in the brothel, argues against this by emphasizing that the brothel creates its own economy in which many people, including local shopkeepers, benefit. She says, "I do not think that esnaf (shopkeep- 
ers) are happy with this decision (of the municipality). There were maybe 1000 people who benefitted from the income generated through the brothel" (Personal interview, May 2015). The marketability of place based on profit-making is a highly selective process which involves "invention of tradition". These are practices cultivated to emphasize continuity with a selective past and traditions (Hobsbawm, 2012, p. 1). Promoting Ulus as an Islamic religious center in Ankara is an attempt to erase the identity of Ulus as a space of diverse and different traditions, and creates a rupture between radical modernity period and sex work based on heterosexuality.

In accordance with the above, revanchism is identified in Ulus as being a two-fold process. Firstly, driven by the logic of (re)claiming the city through opposition to secular constructions and the meanings attached to the district during radical modernity. Secondly, as neoliberal revanchist policies aim to extract profit and surplus value from Ulus' marketability, primarily female sex workers are economically marginalized and further displaced. It can be seen that neoliberal revanchism involves a gendered process in which the meanings of femina grata are both deconstructed and reconstructed, while sex workers remain "femina non grata," just as they have been from the first foundation of the Republic.

\section{Femina Grata versus Femina Communa in the Period of Radical Modernity}

After the the Bentderesi brothels had been abolished in 2005, I heard from an activist for the rights of sex workers that sex workers were looking for clients around the Victory Monument (Zafer Anitı) (Figure 2), so I wandered around the monument, which is located in the heart of Ulus Square, as part of one of my visits to the district. The Victory Monument is at the junction of the now abolished brothels, the Hac1 Bayram Veli Mosque, an important mosque in Ankara, Ankara Castle, and the Anafartalar Shopping Center, the first mall in Ankara, the latter of which is located behind the monument. The monument is therefore a point of passage for anyone who comes to Ulus to visit the mosque, the castle, or simply for going shopping. Many people pass through the square, but one woman who was wandering around in casual clothes, laughing, and, it seemed, flirting with potential clients, attracted my attention. She soon left the square with a man, apparently to go to one of the nearby hotels where sex work is performed. Her presence in the square was in start contrast to the depiction of a woman in the Victory Monument, as I was to notice during later visits.

The reason for choosing the Victory Monument as a starting point for my analysis was its potential for reflec-

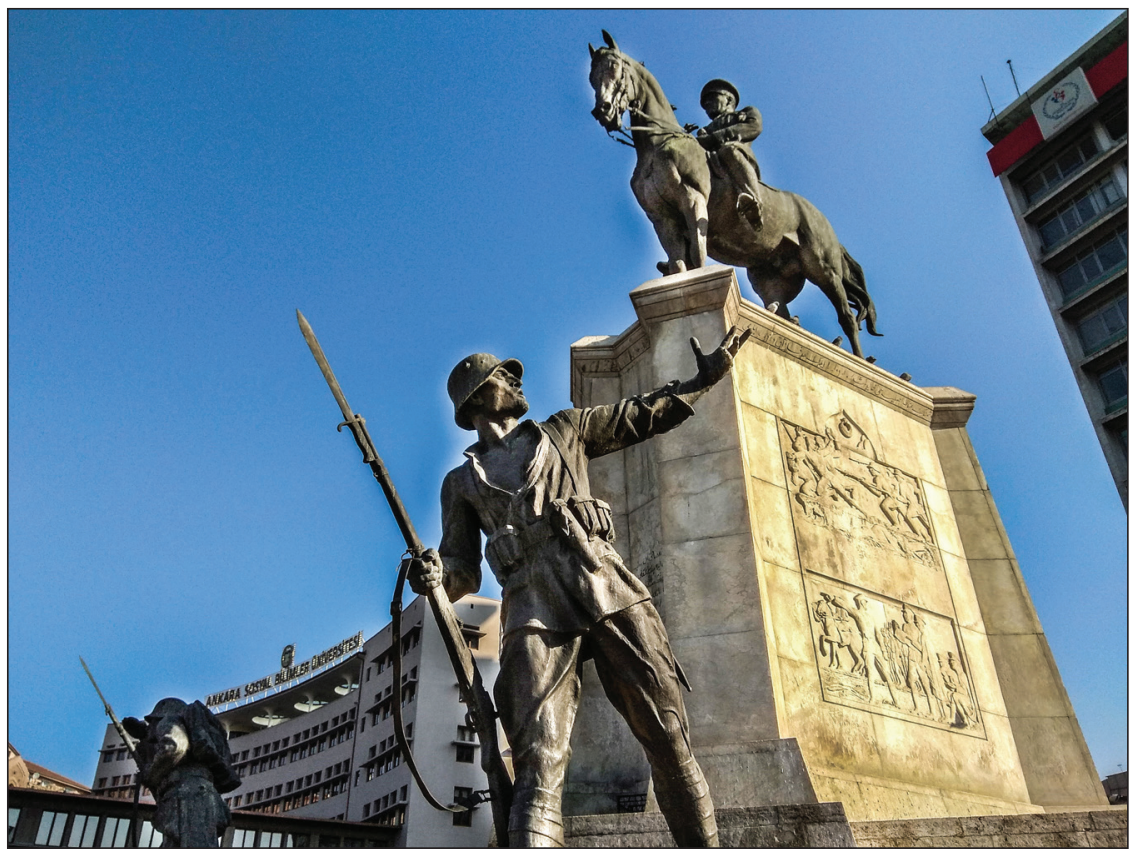

Figure 2. The Victory Monument. Photograph by: Mine Egbatan. 
tion on the political, ideological, and social structures of the period in which it was created. The Monument is a significant symbol in this regard, and it was while I was looking for sex workers for interviews there that I noticed the female figure depicted in the stone relief. It is difficult to spot, not unlike how sex workers in public spaces remain largely invisible. The female sex worker was quite different from the woman depicted in the monument, and it struck me how this was an appropriate representation of the difference between femina grata and femina communa in the radical modernity period.

There are two ways in which this is the case. Firstly, the figures in the monument show who was included, and who was excluded, in the process of nation-building. The female figure offers a starting point for a discussion on the women included in this process. Essentially, one might say that the Turkish nation-building, like any other, was a mainly masculine affair, although it did afford space for women. Secondly, a relationship can be drawn between the concept of security represented in the monument, as well as issues of inclusion and exclusion. Although Batuman $(2005$, p. 37) states that the concept of security is related to enemies, I interpret it as broadly as possible in the radical modernity context of nation-building.

The Victory Monument is a historical symbol produced to reflect the ideology of the newly established Turkish Republic. Created by an Austrian sculptor, Heinrich Krippel, in 1927, the Monument takes as its theme "the Independence War that served as the myth of the rebirth of the Turkish nation" (Batuman, 2005, p. 37). The monument depicts the actors who played a role during the nation-building process, and subsequently those who were included in the construction of the new nation. Ataturk, the founder of the Republic, is positioned at the top of the monument on a horse in military uniform. Two anonymous soldiers are at the front of the monument, and a woman carrying a shell is located behind it. Since the woman has been awarded a position as a constituent member of the new nation-state, this implies that women should be beneficiaries of the reforms of the radical modernity period.

The female figure depicts a peasant woman who is considered to be "brave, patient, self-sacrificing, and active" (Yalım, 2002, p. 203). Such women, who carried munitions to the battlefront (Figure 3), were symbols of modernity in the early Republican period and afterwards.
The critical point here is to consider the conditions under which women were included in the nation-building processes, as emphasized by writer Naşit Hakkı Uluğ (1997, p. 192) during the monument's opening ceremony:

She hugs the shell in her shoulder as if it is her baby. She knows that that the shell is the life of her baby, the glory of her fiancé, the honor of her nation. All these are the assets of our great nation that are complementary to each other.

Protecting the nation's health and well-being was particularly important, as the bloody struggle to protect the nation's existence against anything or anyone who might be considered as being a "threat," such as the wishes of the empires of Europe, was mythologized and considered sacred. However, there was no place for female sex workers in the construction of this new nation, as they were regarded as being "indecent" and possibly even a threat to the nation's well-being. It was therefore to secure the nation and the family as the nucleus of the nation that sex workers were subject to regulatory practices that kept them hidden behind the walls of brothels. As pointed out

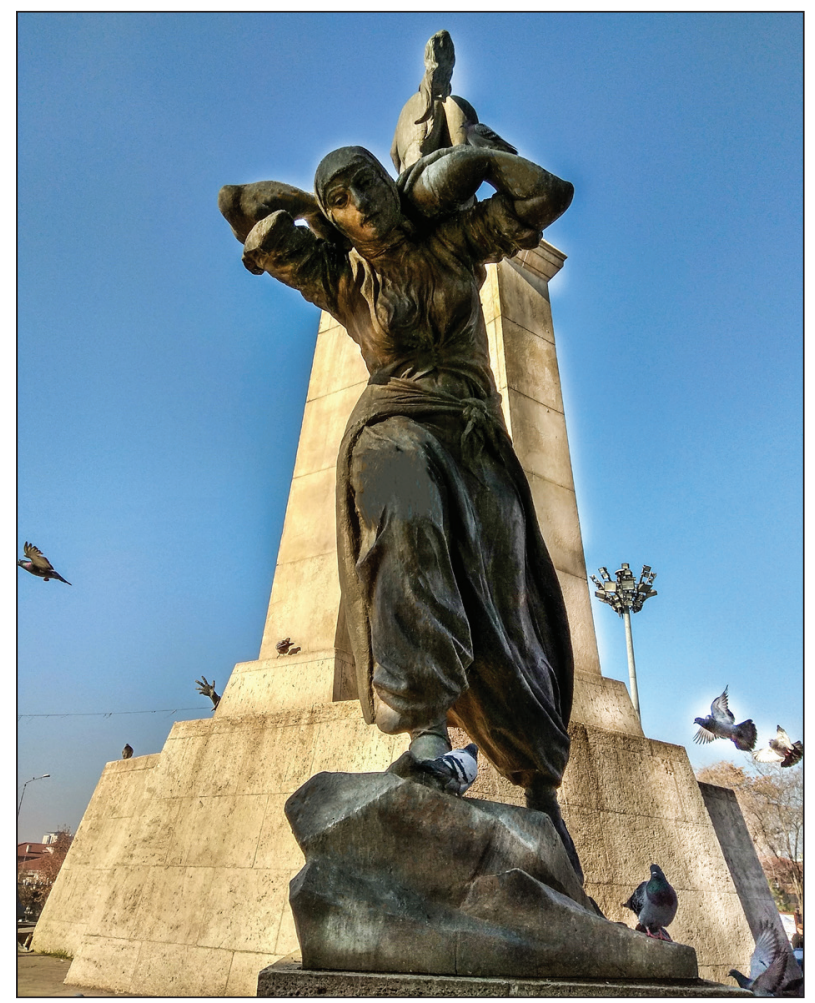

Figure 3. The woman image in the Victory Monument. Photograph by: Mine Egbatan. 
by Kandiyoti and Saktanber (2002, p. 328), although the new regime wanted women to be active and equal members of society, this meant the establishment of "new moral forms of control" in which women were only to be visible in public spaces if their sexuality and gender(s) were left in the private space of the home. According to Kandiyoti (1996, p. 160), the femina grata of radical modernity was embodied in those who were "genderless and stripped of their femininity" in public. In the newly established republican Turkey, a woman's image was constructed as being "modern but virtuous" (Durakbasa \& Ilyasoglu, 2001, p. 196). Manifestly, sex workers were among those who were incompatible with this image. Their presence in public spaces was thus strictly regulated by the law imposed in 1930, as well as subsequent by-laws which were used to regulate the bodies, acts, and practices of sex workers.

\section{The Public Health Law and Regulation of Sex Work}

Sex work is legal in Turkey, and is covered by the Law of Public Health (No. 1593, 1930). In other words, according to this law, together with the by-laws enacted for its the implementation, there is no separation between the legal regulation of sex work and sex workers. How the state thus defines sex workers and sex work has more significant implications for other women than sex workers. Here, instead of considering the private woman as the norm, or the opposite of public woman (the heteronormative "other"), I want to introduce the concept of private woman as being the negation of public woman. In other words, the opposition involved here is one of negation rather than mirror reversal.

I would define the private woman as being a 'decent' woman-that is, an individual who is compatible with the gender roles dictated and decided on by the state. She is also compatible with the political agenda that constitutes the very root of the state. In general, the decent woman who is constructed through the Public Health Law is someone who does not pervert public health and security. This way of viewing the contrast between public and private women enables us to appreciate how male dominance and categorization of 'decent women' is maintained through interpretations of the non-public woman. Thus, while the health and security discourses constitute public women according to the law, the interpretations of non-public (decent) women are subjected to change according to the political period. While the public woman has fundamentally remained the same, as defined in the Public Health Law (with only minor adjustments made by subsequent revisions), perceptions of the nature of the private/decent woman have changed according to the different political projects of modernity, which can be characterized by the period.

As noted (above), the early Republican Turkey's modernization project that was conducted during the period of radical modernity aimed to represent the women of the new regime as being modern/secular and/but virtuous. When introduced in 1930, the Public Health Law was one of the most comprehensive laws of the radical modernity period, and was enacted as part of this project of modernization and public health (i.e., equating or conflating virtue with health). As stated in Article 1, the law's primary purpose was, and remains, to "improve the health conditions of the state, struggle against those diseases affecting public health and ensure better health conditions for future generations" [Author's translation]. The law regulates diseases (malaria and tuberculosis as well as sexually transmitted diseases [STDs]), places, both under state control and privately run (jails, graveyards, hotels), categories of people (migrants, children, workers), and substances (e.g., milk and water).

Syphilis, and other sexually transmitted diseases were targeted by the state during the period of radical modernity in order to ensure "the progress of the nation" (Wyers, 2012 , p. 78). One of the main sources of the disease mentioned in the law is sex workers. As Wyers (2012, p. 78) explains, "the body of the female prostitute was targeted as the prime carrier and disseminator of syphilis, and was thus objectified by increasingly rigid and all-encompassing mechanisms of state power." As well as being one aspect of the wide range of projects engaged for the improvement of the nation's public health, the regulation of sex work also had a security dimension in the sense that sex workers were considered a threat to the nation's wellbeing, family, and women as mothers of new citizens.

The by-law on "the Struggle against Prostitution and Venereal Diseases Spread by Prostitution"6 (No. 15264)

6 Original title of the by-law in Turkish: Fuhuşla ve fuhuş yüzünden bulaşan zührevî hastalıklarla mücadele nizamnamesi, https://www.resmigazete. gov.tr/arsiv/2560.pdf 
was enacted in 1933 to supplement the Public Health Law of 1930. It consisted of eight sections, including definitions of prostitution, the roles and duties of organizational structures in tackling prostitution, the process of medical examination, measures to be taken to prevent women from becoming prostitutes, spaces of prostitution -brothels, rendezvous houses, coupling places (Evered \& Evered, 2011, p. 848) and bordellos (used by one woman as a living and working place), as well as 186 articles other articles related to those sections that are related to the regulation of prostitution.

The first article of the by-law prescribes the establishment of regulatory commissions in the struggle against prostitution. The main purpose of these commissions was, and still is, to "prevent the spread of sexually transmitted diseases due to prostitution and thereby ensure the protection of public order and regulate prostitution" [Author's translation ]. Prostitution has therefore always been represented as a matter of public health and public order/security. As contended by Smart (1989), legal rules often reflect the ideologies in which they are produced. Such concerns were the products of the newly established regime during the period of radical modernity that aimed to create a modern, healthy nation (Alemdaroğlu, 2005). As the basis of the nation, the family needed to be protected against potential dangers and contaminators, and so public health and security concerns became integral to the law. The prostitutes' bodies became an area of state intervention since sex workers are represented as being responsible for the spread of STDs and endangering public health and security/order. This representation has gendered implications beyond public health and security as the boundaries between morality and public health and security blur when an issue is related to a woman's sexuality. These two concerns are therefore primarily used as "apparatuses of moral regulation" (Lupton, 1995).

The by-law (No. 15264, 1933) is still in effect in Turkey, although it underwent some minor amendments in 1961 and 1973. ${ }^{7}$ Significantly, both of these dates may be considered as falling within, and thus marking periods of reconstruction, after military coup d'états in Turkey (in 1960 and 1971). These were periods when masculine and patriarchal structures of society were reinforced and reaffirmed against the perceived threats to the state that prompted the coups. For example, the 1961 constitution reasserted the notion that "family is the basis/foundation of society" (Article 35 ), and such an understanding promotes and privileges the family and its protection. Meanwhile, the relatively unchanged nature of the by-law reflects the continuities and understandings concerning women's sexuality and the patriarchal desire to control women's bodies and sexuality in Turkey. The by-law can therefore also be read as an "attempt to establish a particular system of gender relations" in the country. Since the period of radical modernity, this gender order has been continuously reproduced when prostitution was considered an issue of public health and security.

\section{The Gender Hierarchies of Subjects in the Public Health Law and the Nature of Public Women}

Law and legal regulations play an important role in "maintaining systems that subordinate and oppress female human beings" (Henderson, 1991, p. 1). Patriarchy is produced through the law by creating gender hierarchies and inequalities, as conceptualized by many feminist scholars (e.g., Smart, 1989; MacKinnon, 1989). Reflecting men's views, the law reproduces a system of gender hierarchies in which women are subordinate to and subordinated by men (MacKinnon, 1989). This reproduction of gender hierarchies is closely related to sexuality.

MacKinnon (1982, p. 5-16) argues that sexuality is the main source of male dominance as it results in gender inequalities. He also suggests that "Sexuality is to feminism what work is to Marxism ... the molding, direction, and expression of sexuality organizes society into two sexes, women and men." MacKinnon $(1989$, p. 131) further equates sexuality with heterosexuality, which is also the source of male dominance over the female. As Rubin (1984, p. 165) states, "because sexuality is a nexus of relationships between genders, much of the oppression of women is borne by, mediated through, and constituted within sexuality." It can therefore be seen that sexuality is used as a political tool for the rewarding of some individuals and the suppression of others (Rubin, 1984, p. 171). The laws and regulations regarding prostitution are no exception in their reproduction of gender hierar-

7 The by-law's name was changed to Genel Kadınlar ve Genelevlerin Tabi Olacakları Hükümler ve Fuhuş Yüzünden Bulaşan Zührevi Hastalıklar Tüzü̈̆̈̈. in 1961. 
chies through the definition of prostitutes as "the other of other (women)" (Smart, 1989).

In this context, the Public Health Law of Turkey (No. $1593,1930)$ directly address the subject of public women and lists their character traits. By specifically defining roles for prostitutes, private women, and men in this way, the law reinforces patriarchy and a particular gender order in which prostitutes are placed at the bottom of gender hierarchies. This process denies their individual rights as their bodies, lives, and sexualities become strictly regulated by the state.

This creation by the law of a patriarchal order in which "women's primary purpose is to serve the needs and desires of men," reinforces male dominance in the sense that male sexual desire is formally recognized as requiring satisfaction, and female prostitutes are the sexual objects that are available to and accessible by/to men (Ditmore, 2006, p. 349). Frug (1992, p. 1050) argues that "legal rules permit and sometimes mandate sexualization of the female body," so the public woman's body becomes considered "a body that is for 'sex' with men." According to the 1933 by-law (No. 15264), the public woman is primarily defined as being someone who "practices the art of devoting herself either for gain or habitually and by this means having intercourse with many men for the pleasure of others" (Article 15, [author's translation]). ${ }^{8}$ By excluding men and other gender identities from the definition of prostitution, it is clearly stated that only women can become prostitutes. It is also implied that all men have the right to access the body of the prostitute, unlike the private woman, whose body is only available to her husband. According to this mindset, men who buy sex may, or may not, be married and can easily transgress the boundaries of the public and private woman through their access to both. Due to patriarchal privilege and the normality of their sexual conduct outside the home, men are not considered "immoral" or "indecent." By stating that only women are allowed to work in brothels, a status of gender binary, or heterosexuality, is reinforced.

As Rubin (1984, p. 152) notes, "sexuality that is 'good,' 'normal' and 'natural' should ideally be heterosexual, marital, monogamous, reproductive and non-commercial," with the clear implication that when it is otherwise (e.g., commercial), sexuality is deviant and needs to be controlled and regulated. However, the by-law of 1933 establishes the public woman as someone who frequently serves others (men) for material gain or habitual reasons. Thus, any woman who has sex with many men can be regarded as being a prostitute. Regarding prostitution like this reproduces women into a binary of being decent or indecent. The definition was adjusted in this respect by the 1973 by-law revision of removing "habit" as a definitive feature of public woman:

If a woman is suspected of being engaged in prostitution by having sexual intercourse with many men in a repeated manner and if she is proven to have the attributes of public women as stated in Article $15 \mathrm{after}$ a secret and comprehensive investigation, in the first place, the causes that drove the woman to prostitution are to be investigated by the commission. Measures are then to be taken to have her return to an honorable life. (Article 19, 1933/Article 20, 1961/1973) ${ }^{9}$

The idea of returning women to an honorable life depicts prostitutes as being immoral and prostitution as a disrespectable profession. In this way, the state emphasizes that women need to be in their 'proper' place. The article goes on to explain that the measures taken by the state to have public women return to an honorable life can sometimes be ineffective. This creates another binary, the woman who is forced into prostitution, as opposed to one who actually wants to be a prostitute; the latter being subject to immediate sanction by the state. The article also defines women's bodies and sexualities as being areas subject to control and regulation, since even if women do not practice prostitution, but have sexual intercourse out of wedlock and with many men, they can easily be stigmatized as being indecent and demonized as having the potential to endanger public health and security. In other words, sexuality for women is not acceptable if it is not reproductive.

Quite what is meant as an "honorable" life may vary according to the political inclinations prevailing at any

8 “...kendini başkalarının cinsi zevkine, menfaat karşılığı ya da itiyadi bir surette hasretmeyi sanat edinen ve bu suretle birçok erkekle münasebette bulunan kadın..." (original text in Turkish).

9 "Mükerreren ve birçok erkekle münasebette bulunması dolayısıyla bir kadının fuhşu sanat ettiğinden şüphe edilir ve hakkında gizli ve etraflıca yapılan inceleme ile elde edilen müspet delillerle kendisinin 15. Maddede yazılı genel kadınlar vasıflarına haiz olduğu meydana çıkarılırsa evvela bu kadını fuhşa sürükleyen sebepler araştırllır ve kendisinin tekrar namuslu bir hayata dönmesini sağlayacak tedbirler düşünülür” (original text in Turkish). 
one time (in the different periods of modernity). During periods of radical modernity, an honorable life can be understood as one in which women hide their sexuality in public spaces and fulfill the duty of marriage and motherhood for the future of the nation. Although such an understanding was implicit throughout the by-law, it was not until 1973 that an article (Additional Clause 3), stating that "a married woman cannot work in brothels and bordellos" (No. 7/5786, 1973), was explicitly added to this effect. This addition reinforced the binary between a public woman and a decent woman, as when a woman was married, she was categorized as "decent," and her chastity needed to be protected by the husband, to whom the state delegated the right to her control and regulation. Similarly, a public woman could leave the brothel if she got married, the mentality being as she now belonged to someone then the state no longer needed to monitor her.

The state's concerns for public health and security have placed public women at the bottom of gender hierarchies. When a woman was considered to be a public woman in this system, she was immediately registered as such by the state on her granting registration card (sicil kartonu) (Article 21, 1933/Article 22, 1961). The registration card stated the woman's name, birthplace, place of residence, and the location of the brothel where she works. These registration cards were kept not by the women themselves, but by the commissions responsible for regulating prostitution, although this latter practice was changed in 2012 following a memorandum published by Ministry of the Interior. A public woman is now granted a working certification (hüviyet muayene cüzdanı), commonly known as a vesika. The vesika includes the number (as stated in the registration card), the woman's name and photograph, and records of regular health checks.

This vesika is used as an apparatus of surveillance to keep public women under control and demarcate the boundary between decent and public women. For Foucault (1977, p. 187), surveillance is based on "a principle of compulsory visibility" in which records of individuals are available for "hierarchical observation." The patriarchal power of the state over the bodies of public woman is maintained through the vesika, which enables the state to control their every movement. Thus, the vesika equates to being "known, judged and classified" by "fixing the sta- tus of [the] woman" (Parla, 2001) within the dualism of decent-indecent.

When a vesika is granted to a woman, she is stigmatized in society and can be said to have undergone social death. There is extensive literature on social death and what this involves (e.g., Glaser \& Strauss, 1966; Sudnow, 1967; Kalish, 1968; Patterson, 1982; Card, 2010). It refers to extreme personal or collective loss experienced in the form of displacement, exclusion from citizenship rights, and/or the lack of legal protection (Králová, 2015, p. 236). Public women in Turkey experience social death as their work is associated with their identities, and even though these women are able to keep their official identity cards, their records still reflect that they are/were working in a brothel. The by-law (Article 108) states that "the Commission will protect public women who want to abandon prostitution for Struggling against Venereal Diseases," and that although the "identity cards of those women are returned," they are still "secretly inspected for a while." However, this system is inefficient as when a public woman wants to abandon prostitution, her vesika is not canceled and she continues to be known as a prostitute. This has negative implications on the lives of former sex workers, causing various forms of inequalities.

As prostitutes, former sex workers often do not want, or are not able, to work in the formal economy. For example, Ayşegül, ${ }^{10}$ a former sex worker, told me that she has to work informally for lower wages at her workplace where she cooks lunch as part of her duties. The stigma attached to her as a former prostitute has resulted in her being exploited:

People want to get a job with social security benefits. I am afraid of doing this because if I demand social security benefits, the employers find out that I worked as a prostitute, and their attitude changes as they stop respecting me (Personal interview, June 2014).

The vesika affects public women by denying their rights as citizens and giving them the status of femina non grata, and also makes their children persona non grata. The children of public women cannot work as military officials or in the police. They are considered a threat against the state's very security, and thus against state institutions whose primary purpose is to protect the

10 I used pseudonyms for the names of the interviewees. 
state from any possible threats. The Military Penal Code enforced in 1930 expels military officials if they marry a woman who is either registered as a prostitute or considered to be indecent (iffetsiz) (Article 153). The word "iffetsiz" means without "iffet," the meaning of which is, according to the official Turkish dictionary published by the Turkish Language Association (TDK) as "Adhering to morality in sexual matters, honor." [author's translation] ${ }^{11}$ This cultural norm is operational in every area of women' lives in Turkey.

Article 438 of the Turkish Penal Code (Law No. 65/1926, 1990) recognizes a reduction in punishment when stating the premise that "raping chaste woman is not the same... [as] raping unchaste woman" (Belge, 2011). This logic reinforces the notions of "decent" and "indecent" by representing (female) prostitutes as inferior individuals on the basis that their bodies are considered accessible to all men according to the Public Health Law. In the Turkish Penal Code, sexual assaults against women are categorized under "Felonies against Public Decency and Family Order.” As pointed out by Kurtoğlu (2009, p. 74), rather than being a violation of an individual's rights, rape was considered a breach of public morality and decency, which was at the very root of family order in Turkey. Only private women deserved protection under the law, making women's rights dependent on and meaningful solely within the institution of the family. This article was only removed from the Code in 2004 (Law No. 5237), after intense protests by Turkey's feminist movement.

As prostitution is also made meaningful as an issue of security, the police are granted the authority to take fingerprints and photos, which is used under the Policy Duty Law No. 2559 as a "political tactic of registration identification" (Eşsiz, 2012). This extends the police's role from being simple observers or enforcers of the law to having the right to monitor the conduct and bodies of the public woman as part of their duty to protect the honor and chastity of society (Parla, 2001). Article 5 of the Law $($ No.2559, 1934) allows the police to fingerprint public women. This allows the police to keep records of the public woman by regulating their conduct in order to protect the population from the ills of prostitution. The by-law of 1973 regarding the regulation of prostitution also authorizes the police to identify those who work as prostitutes, and places of prostitution, to reveal any illegal prostitution activities (Article 8).

How the police decide when a woman is working illegally or not appears to be somewhat arbitrary. While Ayşegül was talking about her identification as a prostitute by the police, for example, she directed my attention to the following:

I was sitting with my husband's friend when the police came. They told me that I was working [i.e., as a prostitute] as my husband's friend knew how much money I had in my bag. They took me to be examined. Certain kinds of vaginal discharge can result in you being identified as a prostitute. (Personal interview, June 2014).

The bodies of women are subjected to public interventions if they are regarded as sexually suspect. As Parla (2001, p. 80) states, such examinations are virginity checks used by the state to determine a woman's decency or indecency.

\section{Femina Grata versus Femina Communa in the Neoliberal Revanchist Period}

Yeni Akit (May 19, 2014), a newspaper with conservative political tendencies, blamed sex workers for the moral contamination of a religiously and spiritually significant place in Ulus district after the demolition of Bentderesi. The same news article recalled that the health officials responsible for regulating sex work and sex workers had complained about a legal loophole that led to the punishment of sex workers and control of their movements in and around the Ulus district. The health officials referred to sex workers as "hayat kadını" (lit. "life woman," a traditional term for prostitutes), and were reported as saying that "They can even be your neighbor," a reference to the perceived danger and moral panic that sex workers create. The term "hayat kadıni" is a good starting point from which to discuss the relationship between women and sexuality, since when womanhood is represented in connection to life, street, or sexuality, it not only indicates women who do not belong to the home/private space, but also creates a moral panic suggesting that such women need to be regulated and controlled (Hubbard \& Sanders, 2003; Hubbard, 2004; Caslin, 2010).

11 "Cinsi konularda ahlak kurallarına bağlılık, namus" (Original text in Turkish). 
Bacchi and Eveline (2010, p. 111) consider a policy to be "productive" or "constitutive" in the sense that "policies and policy proposals give shape and meaning to the "problems' they purport to "address." The revanchist urban policies in Ulus that were enacted through the removal of the Bentderesi brothels (Figure 4) consider the sex workspaces and sex workers in the area as being a problem of sanitization/hygiene and security. The spiritual and economic revitalization developments in the district are justified on the basis of such discourses, with the corollary that they also construct the femina grata in accordance with the urban transformation. These two discourses are similar to those used in the radical modernity period to justify the regulatory system which placed sex workers behind the walls of the brothels.

Campkin (2012, p. 5) identifies spaces that are associated with dirt as "spaces of abjection," while Douglas (2003, p. 2) comments that "eliminating [dirt] is not a negative movement, but a positive effort to organize the environment." During the radical modernity period, Turkish society was considered as being like a body which needed to be protected through the incarceration of sex workers as contaminators. On the other hand, during the neoliberal revanchist period, it was seen as a space which has been targeted as a body from which those who are thought to pollute the body have been subject to exclusion. During the interviews I conducted in the municipality, the "dirtiness" of Ulus before the removal of the Bentderesi brothels was frequently mentioned. Melih Gökçek, the former mayor of Ankara, emphasized the importance of removing the brothel "at any cost" (cited in Şengül, 2010, 4 August) and highlighted the brothels as being dirty spaces. This dirtiness was removed through the street rehabilitation projects, a primary concern of the municipality, which changed the aesthetic appearance of the streets and buildings.

Through street rehabilitations, the cleansing or moral sanitization of space is ensured. In this process, sex workers are considered to be conquerors of moral spaces, and both them and their workspaces are associated with the contamination of spiritual places in Ulus. Brothels are associated with dirt, moral contamination, and disrespect of the symbolic meanings of the district. Also, as women's sexuality is associated with dirtiness and danger, veiling becomes a proper dress code for the pious women coming to Ulus who are encouraged to thus hide their sexualities and bodies. Furthermore, in order to ensure the moral sanitation of the space, Bentderesi Street

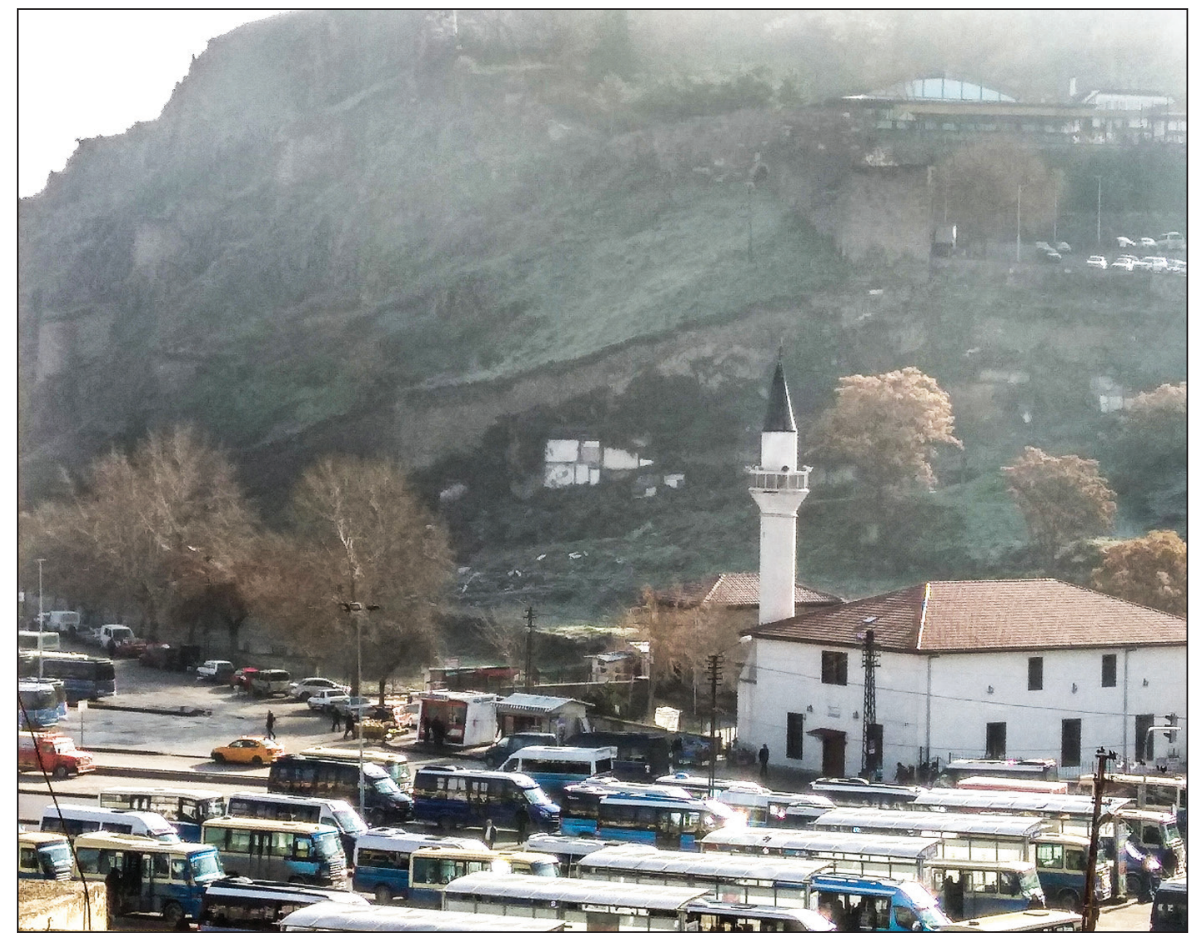

Figure 4. The ruins of Bentderesi Brothel behind the mosque. Photograph by: Mine Egbatan. 
was renamed as Hacı Bayram Street. This is an example of the process described by Massey (1994), who argues that place names are used to delineate the ideological messages of the dominant.

Having promoted the image of the Hacı Bayram Mosque during the urban renewal process, Ulus is now considered to be a safe and crimefree space for pious families. This notion was apparent in the interviews conducted with women working in the municipality, (Personal interview, September 2015):

Of course, removing the brothel contributed to the safety [of Ulus] because those kinds of users went away. It is safe, I mean. During evenings and nights, there was nothing to do here. Now, they can go to the restaurants around Hacı Bayram. There are parks, ponds. It turned out to be a place where people can come and use till night prayer. The municipality expropriated the buildings here and rented them to social associations. They organize iftars during Ramadans that keeps the area lively until the mornings. This makes here safe.

It can be seen that sex workers and sex-work spaces are considered as being criminal and a threat to the security and safety of those women designated as being femina grata in Ulus today. During my informal walks around the Hacı Bayram Veli Mosque, I talked to the women visiting Ulus. They constantly emphasized how safe they felt now that the brothels had been removed, although they usually come to Ulus with their husbands and families during the daytime. This indicates that "clean" and "safe" Ulus only welcomes "decent" women when they are behaving properly, according to religious values.

With the reconstruction of Ulus as a space of "pious" activities, the rhythm of the space has also changed. As Lefebvre (2004) mentions, reading the rhythm of a space is important as it reflects "the dominant spatial order," and that space is constructed and reconstructed through the performances of those who use it. With the symbolic meaning of Ulus having been reconstructed around pious and religious activities, the district now attracts those pious families and women who desire to participate in such activities. The women visiting the $\mathrm{Hac1}$ Bayram Mosque pray, shop, socialize and have picnics there (Figure 5).

Sex workers, however, are not able to find a place within the new rhythm of Ulus, which makes them more mobile and even invisible as they pass through it. Due to everyday violence and the changes in the rhythm of Ulus, sex workers are forced to behave like shadows whose presence is neither desired nor valued. This forced mobility means that they are unable to inscribe their own rhythms on the district. As argued by Tim Cresswell (2010) being mobile constantly is equivalent to being "out of place." This is a result of the changing rhythms of Ulus in which pious families visit the place more often. Yasemin (Personal interview, 2014), a sex worker in Ulus, told me that she appropriated her working spaces according to those families who visit Ulus. For her, this is also a way to escape from the moral gaze of the people visiting the district.

Most of the sex workers were displaced after the removal of the Bentderesi brothel. Some migrated to other cities to try and perform sex work without their support networks, while others started working in the peripheries of Ankara where they were more vulnerable to violence and abuse. Two of my interviewees, Esin and Derin, told me that their friends are working far from the city center and are unable to find help when their customers beat them. Asli, a sex worker in Ulus, told me that she uses corners and blind streets to work where other people are not easily recognizable (Personal interview, 2014). It can be seen that due to various strategies, both legal and illegal, the old rhythms of the city have been broken. While private security services are used to provide pious women and families with a sense of security and safety, sex workers are subjected to constant police intimidation that aims to push them towards the peripheries of the city. Workers are also liable to harsh monetary penalties via the Law of

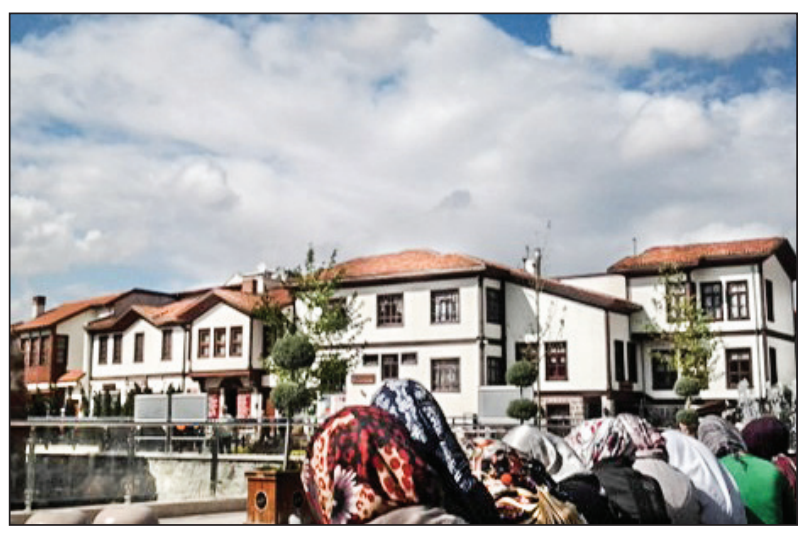

Figure 5. Women socializing around the Hacı Bayram Mosque.

Photograph by: Mine Egbatan. 
Misdemeanor, which punishes sex workers for occupying and 'polluting' the streets. Asli (Personal interview, 2014) continues:

They [the police] consider us to be an inferior class. For example, they get angry and take us to Elmadağ or Gölbaşı and leave us there. They psychologically torture us. They call me by my real name while I am working. When punished, we work harder to pay for the penalties. You even cannot put your money into a bank as they confiscate it.

Asli is well aware of the class (and also gender) hierarchies that harden sex workers' lives. As Ulus has been marketed upon Islamic religious values, sex workers are considered invaluable for the district's ongoing economy. Monetary penalties push sex workers away from the formal economy and trap them in the informal economy. The removal of the Bentderesi brothel results in the reinstating of the masculine economy in the district. Such action provides advantages to the municipality whose decision-makers are men, and the municipality benefits from the increasing marketability of the place through rents. Brothel owners, mostly men, also benefit from selling their houses to the municipality, either through negotiation or by a court decision. Sex workers have a workers status and so do not have control over the brothels they have been working. The money goes to the brothel owners after it has been sold to the municipality. Sex workers are therefore economically excluded and marginalized during all of these processes that make them financially vulnerable.

Through changes in the urban landscape of Ulus, pious women's mobilities are promoted over the mobilities of sex workers. Public spaces are appropriated and turned into spaces for pious activities by excluding certain forms of sexualities and women's bodies. Indeed, public space has not been inclusive for everyone (Sorkin, 1992), and Ulus has not been constructed as a place that welcomes differences. Even as pious women enjoy the district, they challenge the former construction of Ulus as a space of secular and modern Turkey, which is enacted by the expulsion of sex workers. Therefore, any encounter between femina grata and femina communa becomes unlikely based on such spatial politics.

\section{Conclusion: The Triple Dualism of Neoliberal Revanchist Policies}

Feminist theorists argue that the dualisms of masculine and feminine, mind and body, private space and public space, decent and indecent all strengthen, express, and enforce patriarchy. Such dualisms have a political dimension because patriarchy creates hierarchies by promoting one side of the dualism over another (Kristeva, 1986; Cixous, 1988). The theorists emphasize the need to resist a patriarchy that creates inequalities while excluding diversities and differences. I maintain that the construction of a femina grata and femina communa during the neoliberal revanchist period constitutes a historical process - rendered as a moment or configuration - of triple dualism. This triple dualism comprises the oppositional pairings of sex workers-secular women, sex workerspious women, and secular women-pious women, as well as the historical dynamic that exists among them. This is made meaningful through the relationship between space and gender, whose dialectical relationship has been widely discussed in the sense of space as a vehicle for the reproduction of gender inequalities (e.g., Sibley, 1988; Bondi, 1994; Massey, 1994).

This triple dualism, I would argue, functions as a moment of continuity in patriarchy through the reproduction of spatial inequalities, as well as a moment of diversification and multiple constructions of femina grata and femina communa. In other words, the dualisms of sex workerssecular women, sex workers-pious women, and secular women-pious women as reproduced through neoliberal revanchist policies in Ulus target the secular constructions of the nation. The meaning and depictions of the decent woman are thus widened in and through the moment of triple dualism.

Sex workers are constructed as being 'the other' and excluded from shared spaces, while sex workspaces are targeted to cultivate an image of profitable city spaces for capital and to attract those families that enjoy pious activities. The revanchist urban policies pursued in Ulus produce and construct a particular image of the woman who is welcome in public spaces. The symbolic (secular, republican) meaning of Ulus was resisted and subverted by refashioning the district, literally rebuilding it as a religious and spiritual space and creating an economy organized around Islamic religious values. Secular practices, families and women have been excluded from the use of public spaces in Ulus.

Patriarchy is still at work in this, although it changes forms by intervening in the specification of the femina grata. The political projects of the two (radical moder- 
nity and neoliberal revanchist) periods have both utilized women's bodies to promote their ideological stances. ${ }^{12}$ The political inclinations of both have needed the figure of the sex worker as a depiction of 'the other' to privilege their depictions of the ideal woman. Sex workers were targeted to protect the nation's health and well-being during the radical modernity period, and were then excluded from Ulus to safeguard the political and economic profit that was to be gained during the neoliberal revanchist period. The two periods' political inclinations have defined and determined who is to be included and who is to be excluded through the lenses of three patriarchal dualisms.

Revanchism in Ulus is not only a gendered process, but is also distinct from the other representations and practices of the revanchist city that relocate the (upper) middle classes into the city centers. The local state in Ankara, as the representative of national state agencies (Cockburn, 1977), has been responsible for the changing meanings of the Ulus district. Ankara Greater Municipality, under the leadership of Melih Gökçek, the previous mayor of the city, removed the places associated with the radical modernity period where the early Republican Turkey aimed to promote an image of a modern and secular nation. Instead, the religiosity of the Ulus district has been promoted through renting places to lower middleclass shopkeepers and religious associations, as well as through producing spaces for those (pious) lower-middle class families to visit, shop and spend time. Locating the pious lower middle class (and women) in Ulus shows that neoliberal revanchist practices do not have a 'onesize-fits all' formula, and that local political and ideological dynamics shape the ways in which revanchism takes place. Ulus, in its new form, neither welcomes secular women and families (even though they belong to the lower-middle class), nor sex workers who are associated with dirt and immorality.

\section{Acknowledgment}

I would like to thank you Dr. Ayça Kurtoğlu for our discussions about the terms "Femina Grata" and "Femina
Communa", sex worker rights activists from Red Umbrella Sexual Health and Human Rights Association, and sex workers sharing their daily struggles with me.

\section{References}

Aalbers, M. B. (2011). The revanchist renewal of yesterday's city of tomorrow. Antipode, 43(5), 1696-1724.

Alemdaroğlu, A. (2005). Politics of the body and eugenic discourse in Early Republican Turkey. Body \& Society, 11(3), 61-76.

Ankara'nın göbeğinde fuhuş rezaleti! (2014, 19 May). Yeni Akit. Retrieved from https://www.yeniakit.com.tr/haber/ ankaranin-gobeginde-fuhus-rezaleti-18377.html

Atkinson, R. (2003). Domestication by cappuccino or a revenge on urban space? Control and empowerment in the management of public spaces. Urban Studies, 40(9), 18291843.

Bacchi, C. and Eveline, J. (2010). Mainstreaming politics: Gendering practices and feminist theory. Adelaide: University of Adelaide Press.

Batuman, B. (2005). Identity, monumentality, security: building a monument in early Republican Ankara. Journal of Architectural Education, 59(1), 34-45.

Batuman, B. (2015). "Everywhere is Taksim": The politics of public space from nation-building to neoliberal Islamism and beyond. Journal of Urban History, 41(5), 881-907.

Belge, B. (2011). Yargitay üyesinin namus gerekçesi 21 yll öncesinden kalma. Bianet. Retrieved from https://bianet. org/kurdi/kadin/127733-yargitay-uyesinin-namusgerekcesi-21-yil-oncesinden-kalma

Bondi, L. (1994). Gentrification, work and gender identity. In A. L. Kobayashi, (Ed.), Women, Work and Place (p. 182200). Quebec: McGill-Queen's University Press.

Brenner, N., \& Theodore, N. (2002). Cities and the geographies of "actually existing neoliberalism." Antipode, 34(3), 349-379.

Brenner, N. and Theodore, N. (2005). Neoliberalism and the urban condition. City, 9(1), 101-107.

Butler, J. (2012). Can one lead a good life in a bad life? Adorno Prize Lecture. Radical Philosophy, 176, 9.

Card, C. (2010). Confronting evils: Terrorism, torture, genocide. Cambridge: Cambridge University Press.

12 The patriarchies that existed during the AKP period and the period of radical modernity are different from each other regarding their relations to conservatist and secular practices. As Coşar and Yeğenoğlu (2011) assert, traditions, beliefs and family values are at the center of AKP period patriarchy. Social policies have been designed by associating women with the family, such as the discourses about three children, abortion rights, and the removal of the terms "gender" and "equality" in the National Action Plan for Combating Violence. A spatial example of this can be seen in the discourses related to the construction of $1+1$ apartments as being unsuitable for families. 
Caslin, S. (2010). Flappers, amateurs, and professionals: The spectrum of promiscuity in 1920s Britain. In K. Hardy, and S. Kingston (Eds). New sociologies of sex work (p. 11-22). Farnham: Ashgate.

Cixous, H. (1988). Writing differences: Readings from the seminar of Hélène Cixous. Open University Press.

Cockburn, C. (1977). The local state: management of cities and people. Race \& Class, 18(4), 363-376.

Colomb, C. (2012). Pushing the urban frontier: temporary uses of space, city marketing, and the creative city discourse in 2000s Berlin. Journal of Urban Affairs, 34(2), 131-152.

Coşar, S. and Yeğenoğlu, M. (2011). New grounds for patriarchy in Turkey? Gender policy in the age of AKP. South European Society and Politics, 16(4), 555-573.

Cresswell, T. (2010). Towards a politics of mobility. Environment and planning $D$ : society and space, 28(1), 17-31.

Degen, M. M. and Rose, G. (2012). The sensory experiencing of urban design: the role of walking and perceptual memory. Urban Studies, 49(15), 3271-3287.

Ditmore, M. H. (Ed.). (2006). Encyclopedia of prostitution and sex work (Vol. 1). Greenwood Publishing Group.

Doğan, A. E. (2005). Gökçek'in Ankara'yı neo-liberal rövanşçılıkla yeniden kuruşu. Planlama, 4, 130-138.

Douglas, M. (2003). Purity and danger: An analysis of concepts of pollution and taboo. Routledge.

Durakbasa, A. and Ilyasoğlu, A. (2001). Formation of gender identities in republican Turkey and women's narratives as transmitters of herstory' of modernization. Journal of Social History, 35(1), 195-203.

Edensor, T. (2010). Walking in rhythms: place, regulation, style and the flow of experience. Visual Studies, 25(1), 69-79.

Eşsiz, V. (2012). Devletin eli beli sopası: Anlatılmamış sürgünden kabahatlere Türkiye'de trans bedenin denetimi. In C. Çakırlar, and S. Delice (Eds.), Cinsellik muamması: Türkiye'de queer kültür ve muhalefet (s. 185-220). Istanbul: Metis Yayınları.

Evered, E. Ö. and Evered, K. T. (2013). Sex and the capital city: the political framing of syphilis and prostitution in early republican Ankara. Journal of the History of Medicine and Allied Sciences, 68(2), 266-299.

Evered, E. Ö. and Evered, K. T. (2013). Protecting the national body: regulating the practice and the place of prostitution in early republican Turkey. Gender, Place \& Culture, 20(7), 839-857.

Foucault, M. (1977). Discipline and punishment: The birth of the prison. New York, NY: Random.

Frug, M. J. (1992). A postmodern feminist legal manifesto (an unfinished draft). Harvard Law Review, 1045-1075.
Glaser, B. G. and Strauss, A. L. (1966). Awareness of dying. (1st ed.). Routledge. https://doi.org/10.4324/9781351327923

Henderson, L. (1991). Law's patriarchy. Law \& Society Review, 25(2), 411-444.

Hobsbawm, E. and Ranger, T. (Eds.). (2012). The invention of tradition. Cambridge: Cambridge University Press.

Hubbard, P. (2004). Revenge and injustice in the neoliberal city: uncovering masculinist agendas. Antipode, 36(4), 665-686.

Hubbard, P. and Sanders, T. (2003). Making space for sex work: Female street prostitution and the production of urban space. International Journal of Urban and regional research, 27(1), 75-89.

Türk Dil Kurumu (TDK). İffet. Güncel Türkçe Sözlük. Retrieved from https://sozluk.gov.tr/

Kalish, R. A. (1968). Life and death: dividing the indivisible. Social Science and Medicine, 2, 249-259.

Kandiyoti, D. (1996). Gendering the Middle East: Emerging perspectives. New York: Syracuse University Press.

Kandiyoti, D., Bora, A., Sayılan, F., Tekeli, Ş., Tapınç, H. and Özbay, F. (2013). Cariyeler, bacılar, yurttaşlar: kimlikler ve toplumsal dönüşümler. İstanbul: Metis Yayınları.

Kandiyoti, D., and Saktanber, A. (Eds.). (2002). Fragments of culture: The everyday of modern Turkey (1st edition). New Brunswick, N.J: Rutgers University Press.

Králová, J. (2015). What is social death? Contemporary Social Science, 10(3), 235-248.

Kristeva, J. (1986). The kristeva reader. New York: Columbia University Press.

Kurtoğlu, A. (2009). Erkek egemenliği, kültürel şiddet ve hukuk. Toplum ve Bilim, 114, 74-97.

Lefebvre, H. (1991). The production of space. Oxford: Blackwell.

Lefebvre, H. (2004). Rhythmanalysis: Space, time and everyday life. (S. Elden and G. Moore, Trans.). London; New York: Continuum.

Lupton, D. (1995). The imperative of health: Public health and the regulated body. SAGE. https://www.doi. org/10.4135/9781446221976

MacKinnon, C. A. (1982). Feminism, Marxism, method, and the state: An agenda for theory. Signs, 7(3), 515-544.

MacKinnon, C. A. (1989). Toward a feminist theory of the state. Cambridge: Harvard University Press.

Massey, D. (1994). Space, place, and gender. Durham: University of Minnesota Press.

Parla, A. (2001). The "honor" of the state: Virginity examinations in Turkey. Feminist Studies, 27(1), 65-88.

Pateman, C. (1983). Defending prostitution: charges against ericsson. Ethics, 93(3), 561-565. 
Patterson, H. O. (1982). Slavery and social death: A comparative study. London: Harvard University Press.

Pratt, A. C. (1997). The Cultural industries production system: A case study of employment change in Britain, 1984-91. Sage Journals, 29(11), 1953-1974.

Pink, S. (2007). Walking with video. Visual studies, 22(3), 240252.

Rubin, G. S. (1984). Thinking sex: Notes for a radical theory of the politics of sexuality. In E. C. S. Vance (Ed.), Pleasure and danger: Exploring female sexuality. Boston: Routledge \& Kegan Paul.

Schinkel, W., Suvarierol, S. and Van Houdt, F. (2011). Neoliberal communitarian citizenship: Current trends towards earned citizenship in the United Kingdom, France and the Netherlands. International Sociology, 26(3), 408432.

Sibley, D. (1988). Survey 13: Purification of space. Environment and Planning D: Society and Space, 6(4), 409-421.

Smart, C. (1989). Feminism and the power of law. London; New York: Routledge.

Smith, N. (1996). The new urban frontier: Gentrification and the revanchist city. London; New York: Routledge.

Smith, N. (2002). New globalism, new urbanism: gentrification as global urban strategy. Antipode, 34(3), 427-450.

Sorkin, M. (Ed.). (1992). Variations on a Theme Park: the new American city and the end of public space. New York: Hill and Wang.

Sudnow, D. (1967). Passing on. Englewood Cliffs, NJ: Prentice Hall.
Swanson, K. (2007). Revanchist urbanism heads south: The regulation of indigenous beggars and street vendors in Ecuador. Antipode, 39(4), 708-728.

Şahin, U. (2017, 25 June). AKP'nin amacı mimariyi de muhafazakârlaştırmak! Birgün.

Retrieved from https://www.birgun.net/haber/akp-nin-amacimimariyi-de-muhafazakarlastirmak-166609

Şengül, T. (2010, 4 August). Geneleve özel yaklaşımlar: Kirlilik ve tehdit algısı. Birgün. Retrieved from https://www.birgun. net/haber/geneleve-ozel-yaklasimlar-kirlilik-ve-tehditalgisi-11989

Tekeli, İ. (2010). The story of Istanbul's modernisation. Architectural Design, 80(1), 32-39.

Uitermark, J. and Duyvendak, J. W. (2008). Civilising the city: Populism and revanchist urbanism in Rotterdam. Urban Studies, 45(7), 1485-1503.

Uluğ, H. N. (1997). Hemşehrimiz Atatürk. Ankara: Türkiye İş Bankası Kültür Yayınları.

Wright, M. W. (2006). Public women, profit, and femicide in northern Mexico. South Atlantic Quarterly, 105(4), 681698.

Wyers, M. D. (2012). The wicked Istanbul: The regulation of prostitution in Early Turkish Republic. Istanbul: Libra Book.

Yalım, İ. (2002). Toplumsal belleğin ulus meydanı üzerinden kurgulanma çabası. In G. A. Sargın (Ed.), Ankara'nın kamusal yüzleri. Başkent üzerine mekân-politik tezler (p. 157-214). İstanbul: İletişim. 